\title{
Cytogenetic Characterization of Aloysia virgata Ruiz and Pavan (Verbenaceae)
}

\author{
Aline Dias Brandão ${ }^{1}$, Lyderson Facio Viccini ${ }^{2}$ and Shirlei Maria Recco-Pimentel ${ }^{1 *}$ \\ ${ }^{1}$ Departamento de Biologia Celular; Instituto de Biologia; Universidade Estadual de Campinas; C.P.: 6109; 13083- \\ 863; Campinas - SP - Brasil. ${ }^{2}$ Departamento de Biologia; Instituto de Ciências Biológicas; Universidade Federal \\ de Juiz de Fora; 36036-330; Juiz de Fora - MG - Brasil
}

\begin{abstract}
Since previous cytogenetic reports of Aloysia have only described the meiotic behavior and chromosomal number of some species, the aim of this work was to provide detailed cytogenetic description of Aloysia virgata that would contribute to the understanding of the taxonomical organization of the Verbenaceae. Aloysia virgata had a karyotype with $2 n=36$ metacentric chromosomes, all with similar size. The large amount of heterochromatin seen after Giemsa staining was confirmed by C-banding. Four nucleolar organizer regions (NORs) were detected with an rDNA 45S probe in two homologous pairs and two sites of $5 S$ rDNA located on one chromosomal pair were detected by fluorescence in situ hybridization. The interphase nucleus was classified as semi-reticulate. Meiotic analysis showed a normal chromosomal behavior, with 18 bivalents in some parts of prophase I and in metaphase I. The number of chromosomes, NORs and 5S rDNA segments did not exclude a possible polyploid origin.
\end{abstract}

Key Words: Chromosome, Cytogenetic characterization, FISH, Aloysia, Verbenaceae

\section{INTRODUCTION}

The genus Aloysia was described by Ortega and Patau in 1807 and contained about 30 species, widely distributed in America, from the southern USA and Mexico to northern Patagonia (Botta, 1979, 1980; Troncoso, 1980). The taxonomical limits of the genus are not well defined and Aloysia species have frequently been included in other genera that are morphologically similar to Aloysia, e.g. Lippia. This has resulted in some confusion in identifying Aloysia species (Sanders, 1987, 2001; Salimena, 2000, 2002).

There have been few cytogenetic studies of the family Verbenaceae. The small size of the chromosomes and the reduced size of the flowers make cytogenetic analyses difficult (Kummar and Dutt, 1989). Cytogenetic studies have been reported for only five of the 30 well-known species: A. grattisima (Gill. and Hook.) and $A$. lycioides Cham. with $2 \mathrm{n}=54$ (Corazza-Nunes et al., 1995; Andrada et al., 1998), A. ligustrina (Gill. and Hook.) and A. polystachya (Gris.) with $2 \mathrm{n}=$ 36 (Covas and Schnack, 1946 apud CorazzaNunes et al., 1995; Andrada et al., 1998) and A. scorodonioides HBK with 2n = 72 (Diers, 1961 apud Corazza-Nunes 1995).

Since cytogenetic studies are an important tool for understanding the phylogenetic relationships and systematics of plants and since previous cytogenetic reports of Aloysia have only described the meiotic chromosomal behavior and

\footnotetext{
* Author for correspondence: shirlei@unicamp.br
} 
chromosome number for a few species, the aim of this work was to provide a detailed cytogenetic analysis that would contribute to the understanding of the cytogenetics of the Verbenaceae and of the taxonomical organization of this group.

\section{MATERIAL AND METHODS}

\section{Plant material}

Five hundred seeds of $A$. virgata were collected from at least 10 trees in the Reserva Municipal Santa Genebra (220 4945"S, 47006'33"W), Campinas, SP, Brazil. Only one voucher specimen (accession $n^{\circ}$ 39.308) was deposited in the CESJ Herbarium at the Universidade Federal de Juiz de Fora (UFJF).

\section{Sample and slide preparation}

The seeds collected from different trees were placed in Petri dishes and incubated in a germinator on a $12 \mathrm{~h}$ photoperiod at $25^{\circ} \mathrm{C}$ until the root emission. The root stips were pre-treated with $12 \mu \mathrm{M}$ oryzalin at room temperature for $5 \mathrm{~h}$ and then washed and fixed with fresh, cold methanol:acetic acid solution $(3: 1, \mathrm{v} / \mathrm{v})$ for at least $24 \mathrm{~h}$. Enzymatic maceration was done with a Pectinex (Novo Nordisk ${ }^{\mathrm{TM}}$ ): $2 \mathrm{mM}$ sodium citrate mixture $(1: 10, \mathrm{v} / \mathrm{v}), \mathrm{pH} 3.5$, at $34{ }^{\circ} \mathrm{C}$ for $1 \mathrm{~h}$. The slides were prepared by the air drying technique (Carvalho, 1995).

For meiotic analysis, immature inflorescences were fixed in the fresh, cold methanol:acetic acid solution $(3: 1, \mathrm{v} / \mathrm{v})$. Meiotic preparations were obtained using air drying technique with enzymatic maceration. Twelve flowers and about 40 anthers were used. After fixation, the anthers were transferred to an adapted tube with a polyester screen at the bottom. The material was washed with the distilled water for $10 \mathrm{~min}$ and the adapted tube with anthers was then immersed in a concentrated enzymatic solution at $34^{\circ}$ for $20 \mathrm{~min}$, after which the anthers were washed with the distilled water for $10 \mathrm{~min}$. The adapted tube was then placed in the microtube $(0.5 \mathrm{~mL})$ containing distilled water in which the anthers were broken into fragments with a special needle to collect the pollen mother cells (PMCs). The cell suspension was centrifuged four times at $4000 \mathrm{rpm}$ (three min each). After the fourth centrifugation, fresh, cold fixative (methanol:acid acetic, 3:1, v/v) was added to complete the microtube volume. After 20 minutes, the cells were resuspended and about six drops of the suspension were used for slide preparation. After drying on a hot plate, the slides were submerged in $45 \%$ acetic acid for $10 \mathrm{~s}$ and then dried again and stained with 10\% Giemsa solution (pH 6.8) for $90 \mathrm{~s}$.

\section{Interphase nuclei}

The morphology of nearly 1000 interphase nuclei was analyzed after Giemsa staining and the nuclei were classified according to Guerra (1987a, b).

\section{C-Banding}

Constitutive heterochromatin was detected as described by Schwarzacher et al. (1980), with slight modifications. The slides were incubated in $0.2 \mathrm{~N} \mathrm{HCl}$ at room temperature for $75 \mathrm{~s}$, treated with $5 \%$ barium hydroxide at room temperature for $8 \mathrm{~min}$ and finally incubated with $2 \times \mathrm{SSC}$ at 60 ${ }^{\circ} \mathrm{C}$ for $80 \mathrm{~min}$. The staining was done with Giemsa solution for $15 \mathrm{~min}$.

\section{Fluorescence in situ hybridization (FISH)}

Fluorescence in situ hybridization was done according to Heslop-Harrison et al. (1991), with a few modifications. The probes pTa71 containing 18S-5.8S-26S rDNA and pTa794 containing 5S rDNA sequences, both isolated from wheat (Gerlach and Bedbrook, 1979; Gerlach and Dyer, 1980) were used. The probes were labeled with biotin by nick translation. The preparations were incubated with RNAse $(100 \mu \mathrm{g} / \mathrm{mL})$ at $37^{\circ} \mathrm{C}$ for 1 $\mathrm{h}$ and then post-fixed in $4 \%(\mathrm{w} / \mathrm{v})$ paraformaldehyde, dehydrated in a $70-100 \%$ graded ethanol series and air dried. The hybridization mixture $(30 \mu \mathrm{l} / \mathrm{slide})$ consisted of $100 \%$ formamide $(15 \mu \mathrm{l}), 50 \%$ dextran sulphate $(6$ $\mu 1), 20 \times \operatorname{SSC}(3 \mu \mathrm{l})$, denatured blocking DNA (100 ng/slide), 10\% SDS $(1 \mu \mathrm{l})$ and probe $(100-$ $200 \mathrm{ng} / \mathrm{slide})$. The mixture was denatured at $70{ }^{\circ} \mathrm{C}$ in a moist chamber and quickly chilled on ice. Chromosome denaturation was done at $90{ }^{\circ} \mathrm{C}$ for $10 \mathrm{~min}, 48^{\circ} \mathrm{C}$ for $10 \mathrm{~min}, 38^{\circ} \mathrm{C}$ for $5 \mathrm{~min}$ and $37{ }^{\circ} \mathrm{C}$ for $5 \mathrm{~min}$ using a PTC 100 thermal cycler (MJ Research). Hybridization was done at $37^{\circ} \mathrm{C}$ in a moist chamber overnight. Post-hybridization washes were done in $20 \mathrm{x}$ SSC for 45S rDNA and in $6 \times \mathrm{SSC}$ for $5 \mathrm{~S}$ rDNA, always with constant shaking. The hybridization sites were detected with an avidin-FITC conjugate. The chromosomes were counterstained with propidium iodide solution $(2.5 \mathrm{mg} / \mathrm{mL})$ and the slides were mounted in VectaShield antifade (Vector Laboratories). 


\section{Meiosis}

About 100 cells in each stage of meiosis were analyzed and identified using meiotic images of Hordeum, Artemisia and Zea mays, as described by Singh (1993) and Fukui and Nakayama (1996).

\section{RESULTS}

Twenty metaphases were analyzed to determine the chromosomal number. There were $2 n=36$ metacentric chromosomes, all with similar size (Fig. 1a).

Blocks of chromatin that stained strongly with Giemsa were seen in mitotic chromosomes (Fig. 1a). C-Banding (Fig. 1b) coincided with these blocks, indicating a large amount of heterochromatin. The interphase nucleus was classified as semi-reticulate, according to Guerra (1987a) (Fig. 1c).

Since the localization of active NORs by Ag-NOR technique (Howell and Black, 1980) resulted in non-specific staining, FISH was used, which revealed four rDNA 45S sites in two homologous pairs (Fig. 1d). Two signals regions of 5S rDNA were also seen in one homologous pair (Fig. 1e). Cells at different meiotic phases were observed in middle pachytene (Fig. 2a), middle diplotene (Fig. 2b), diakinesis (Fig. 2c), anaphase I (Fig. 2d), telophase I (Fig. 2e) and final telophase II (almost tetrad) (Fig. 2f). No signs of meiotic irregularities were observed. Eighteen bivalents were seen during diakinesis (Fig. 2c).
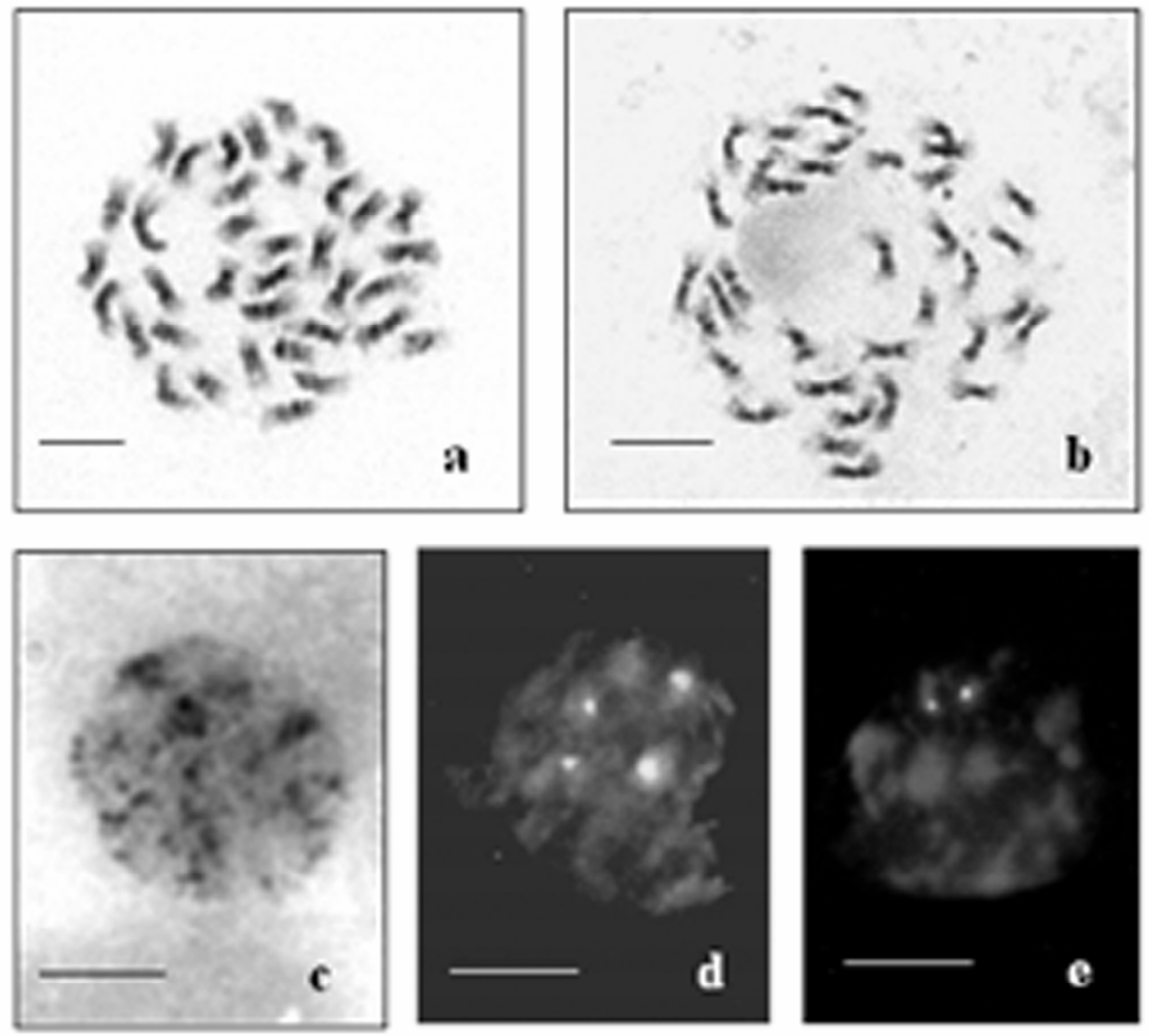

Figure 1 - Mitotic cells: metaphase (a) stained with Giemsa 10\%. Metaphase after C-banding (b). Interphase nuclei (c) stained with Giemsa 10\%. Interphase showing four NORs (d) and two segments of 5S rDNA (e) with FISH. Bar $=6 \mu \mathrm{m}$. 

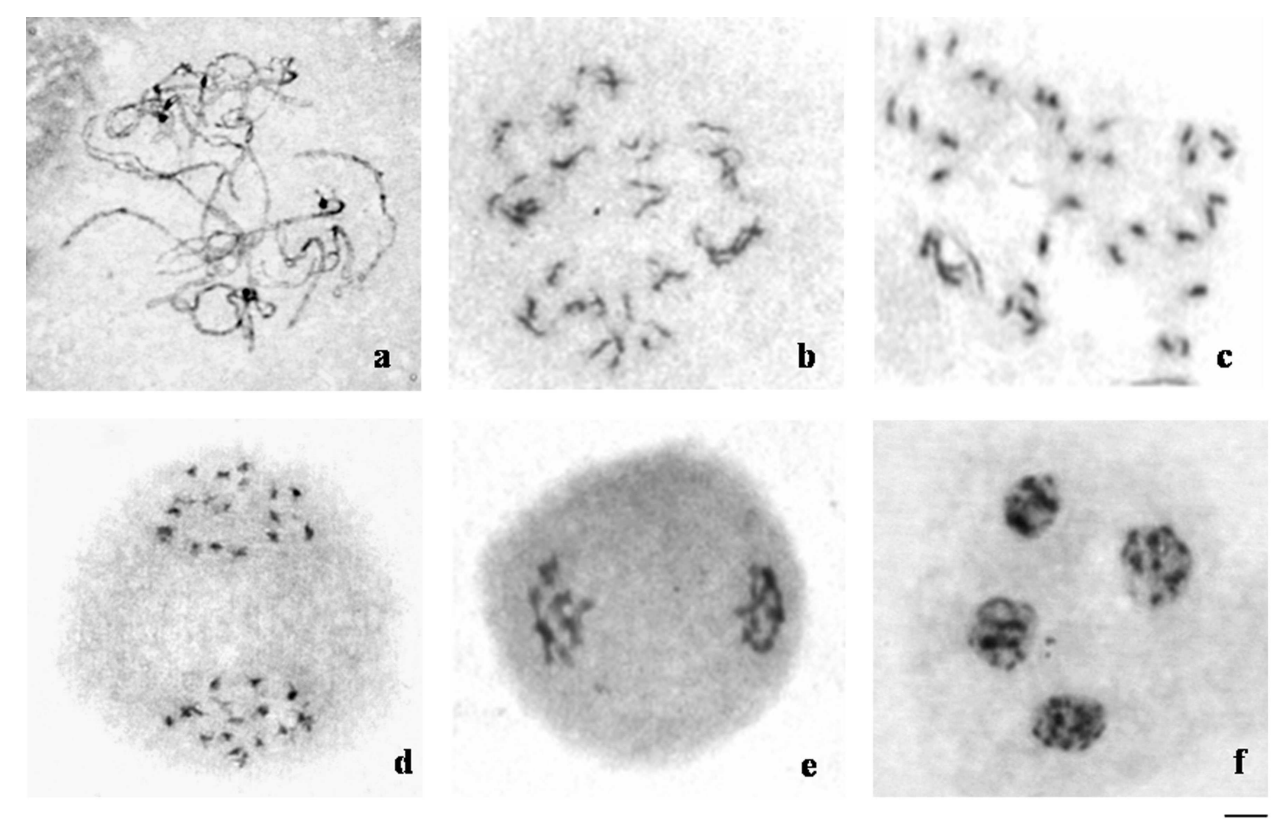

Figure 2 - Meiotic cells: middle pachytene (a), middle diplotene (2b), diakinesis (c), anaphase I (d), telophase I (e) and final telophase II (f) $\mathrm{Bar}=8.5 \mu \mathrm{m}$.

\section{DISCUSSION}

Cytogenetic analysis of $A$. virgata revealed $2 \mathrm{n}=$ 36 small metacentric chromosomes. Previous cytogenetic studies of this genus reported chromosomal numbers of $2 \mathrm{n}=36,54$ and 72 (Corazza-Nunes et al., 1995; Andrada et al., 1998). Since the basic number proposed for Aloysia is $\mathrm{x}=$ 9 (Corazza-Nunes et al., 1995), and since polyploidy is very common in plants (for reviews see Otto and Whitton, 2000; Stace, 1989; Wendel, 2000; Schmidt, 2002), a polyploid origin for $A$. virgata is possible. Based on this hypothesis, the $2 \mathrm{n}=36$ found in A. virgata, A. ligustrina and A. polystachya could be considered tetraploid, whereas the $2 \mathrm{n}=54$ in A. grattisima and $A$. lycioides as hexaploid and the $2 \mathrm{n}=72$ in $A$. scorodonioides as octaploid, in agreement with the basic number of $\mathrm{x}=9$ proposed by Corazza-Nunes et al. (1995).

Previous studies of seed viability, pollen fertility and meiotic chromosomal behavior in Aloysia revealed many abnormalities (as univalent, trivalent, tetravalent, pentavalent and hexavalent associations during prophase I, early segregation during metaphase I, telophase I and metaphase II, multiple and multipolar spindles in anaphase II, several nuclei of different sizes in telophase II and tetrads with 3 to 8 microspores of unequal size) associated with a high percentage of sterile pollen and a low index of seed germination (CorazzaNunes et al., 1995). These alterations have been related to polyploidy. Cytological evidence for an association between sterility and a high level of ploidy was also reported by Abraham and Gopinathan (1991) for Dioscorea alata L. (Dioscoreaceae). Khoshoo and Mahal (1967), Natarajan and Ahuja (1957) and Raghavan and Arora (1960) found meiotic irregularities and seed sterility in Lantana populations in India. Aloysia virgata showed a regular meiotic behavior with a high percentage of seed germination (about 80\%), unlike Aloysia species.

If $A$. virgata has tetraploid origin, the meiotic success observed here could be explained by genic control of the pairing of distinct genomes in an alotetraploid or a high degree of homology between the genomes (Riley and Chapman, 1958; Sybenga, 1996; Dagne, 2001). A regular meiotic behavior may also be indicative of polyploidy established by diploid-like behavior at meiosis (De Wet, 1979; Widen and Widen, 2000; Ozkan et al., 2001; O'Leary et al., 2004). An additional hypothesis is that natural selection may have eliminated the eventual problems caused by chromosomes with a normal meiotic behavior. FISH with rDNA probes provided an important cytogenetic marker for defining the number of 
NORs and revealed only one chromosomal pair with 5S rDNA sites in Aloysia. This result would be possible for a tetraploid species if chromosomal reorganization and DNA elimination occurred during polyploidization, proposed by Eckardt (2001).

No report has described Aloysia species with $2 \mathrm{n}=$ 18. However, this lack of evidence does not allow to definitively discard $2 n=36$ as a diploid number for $A$. virgata, with $\mathrm{x}=18$. Some authors have also suggested a high basic chromosomal number for other genera when compared with those for angiosperms $(x=7)$ (Raven, 1975). Other examples include Chroranthus and Sarcandra $(\mathrm{x}=$ 15) (Okada,1995), Euphrasia $(\mathrm{x}=11)$ (Barker et al., 1987), Clerodendrum (Verbenaceae) $(\mathrm{x}=15$, 23 and 26) (Choudhary and Roy, 1983; Moldenke, 1985), Artemisia $(\mathrm{x}=17)$ and Brassica $(\mathrm{x}=18)$ (Stace, 2000); Rosaceae ( $\mathrm{x}=17$ ) (Ramam and Kesavan, 1963) and Boronia $(\mathrm{x}=18)$ (Shan et al., 2003). Yang et al. (2000) described for Pyrenaria basic chromosomal number $\mathrm{x}=15$ and concluded that all of the species investigated were diploid. These authors suggested that polyploidization during evolution could explain the high basic number for each genus studied.

Heterochromatin is one of the most important factors in evolution (Edelman and Lin, 1995) since it can interfere with phenomena such as DNA replication, nuclear volume, cell size, chromosomal structure, gene expression, genome organization, cell cycle and developmental rate (Stace, 2000; Redi et al., 2001). Variations in the amount of heterochromatin have proven to be useful in karyosystematic and phylogenetic studies (Schwarzacher et al., 1980; Grif, 2000). As shown here, A. virgata had a large amount of heterochromatin. At the supra- and infra-generic levels in plants, large amounts of heterochromatin are considered to represent an accumulation during evolution (Ikeda, 1988; Roser, 1994). Studies of the longitudinal differentiation of chromosomes in some Sesbania species have suggested that a large amount of heterochromatin indicates evolutionary differentiation within the genus, while a small amount of heterochromatin represents an ancestral condition (Forni-Martins and Guerra, 1999). A similar conclusion was reached by Greilhuber et al. (1981) and Moscone et al. (1996) for other genera. Hence, it could be possible that the large amount of heterochromatin seen in A. virgata represented an apomorphic condition for this species, but it would be necessary to analyze other species of Aloysia genus to confirm this hypothesis.

\section{ACKNOWLEDGMENTS}

The authors thank Dr. IFM Válio and FM Scarpa for harvesting the seeds; to Dr FRG Salimena for identifying the plants and for harvesting the inflorescences, Dr AL Cortelazzo for use of the germinator, Dr ALL Vanzela for helping with the FISH experiments and Dr ERF Martins for valuable discussions. This work was supported by FAPESP (grant Proc. no. 2000/11842-2).

\section{RESUMO}

O gênero Aloysia reúne aproximadamente 30 espécies, porém sua circunscrição tem sido motivo de controvérsia. São poucos os estudos citogenéticos para o gênero, relatando apenas o número e o comportamento cromossômico. $\mathrm{O}$ presente trabalho teve como objetivo, identificar os caracteres citogenéticos de Aloysia virgata da flora brasileira que possam ser utilizados para um melhor entendimento e caracterização dos aspectos citogenéticos da família Verbenaceae, que possam contribuir para a organização taxonômica do grupo. Aloysia virgata apresentou cariótipo com $2 \mathrm{n}=36$ pequenos cromossomos, todos com o mesmo tamanho. Grande quantidade de heterocromatina foi observada com Giemsa e confirmada pela técnica de banda C. Foram detectadas quatro regiões organizadoras de nucléolo (NORs) e dois sítios de rDNA 5S pela técnica de hibridação in situ fluorescente (FISH). O núcleo interfásico foi classificado como semireticulado. Foi realizada a caracterização meiótica, na qual os cromossomos apresentaram comportamento normal, com a presença de 18 bivalentes na prófase I e na metáfase I. O número de cromossomos, de NORs e de segmentos de DNAr 5S não excluem uma possível origem poliplóide.

\section{REFERENCES}

Abraham, K. and Gopinathan, N. P. (1991), Polyploidy and sterility in relation to sex in Dioscorea alata L. (Dioscoreaceae). Genetica, 83, 93-97. 
Andrada, A. B.; Pastoriza, A. and Martínez-Pulido, L. V. (1998), Citogenética en tres especies de Verbenaceas. Rev. Fac. Agron., 15, 312-318.

Barker, W. R.; Kiehn, M. and Vitex, E. (1987), Chromosome numbers in Australian Euphrasia (Scrophulariaceae). Plant Syst. Evol., 158, 161-164.

Botta, S. M. (1979), Las espécies argentinas del género Aloysia (Verbenaceae). Darwiniana, 22, 67-108.

Botta, S. M. (1980), Las espécies del gênero Acantholippia (Verbenaceae). Darwiniana, 22, 511532.

Carvalho, C. R. (1995), Desenvolvimento de tecnologia citogenética em milho (Zea mays L.). PhD Thesis, Universidade Federal de Viçosa, Minas Gerais, Brasil Choudhary, S. S. and Roy, R. P. (1983), Karyological studies and trend of speciation in some members of Verbenaceae. Cytologia, 48, 735-74.

Corazza-Nunes, M. J.; Pagliarini, M. S.; Silva, N. and Silva, I. (1995), Hexaploidy and fertility interelationships in Aloysia lycioides (Verbenaceae). Rev. Fac. Agron., 38, 627-630.

Dagne, K. (2001), Cytogenetics of new Guizotia Cass. (Compositae) interspecific hybrids pertaining to genomic and phylogenetic affinities. Plant Syst. Evol., 230, 1-11.

De Wet, J. M. (1979), Origins of polyploids. Basic Life Sci., 13, 3-15.

Eckardt, N. A. (2001), A sense of self: the role of DNA sequence elimination in allopolyploidization. Plant Cell, 13, 1699-1704.

Edelman, J. R. and Lin, Y. J. (1995), Repetitive DNA/heterochromatin: can it be the "driving force" of evolution and speciation? Cytobios, 83, 117-127.

Forni-Martins, E. R. and Guerra, M. (1999), Longitudinal differentiation in chromosomes of some Sesbania Scop. species (Fabaceae). Caryologia, 52, 87-103.

Fukui, K. and Nakayama, S. (1996), Plant chromosomes: laboratory methods. CRC Press. Boca Raton.

Gerlach, W. L. and Bedbrook, J. R. (1979), Cloning and characterization of ribosomal RNA genes from wheat and barley. Nucl. Acids Res., 7, 1869-1885.

Gerlach, W. L. and Dyer, T. A. (1980), Sequence organization of the repeating units in the nucleus of wheat which contains 5S-rRNA genes. Nucl. Acids Res., 8, 4851-4865.

Greilhuber, J.; Deumling, B. and Speta, F. (1981), Evolutionary aspects of chromosome banding, heterochromatin, satellite DNA, and genome size in Scilla (Liliaceae). Berichte Deuts. Bot.Gesell., 94, 249-266.

Grif, V. G. (2000), Some aspects of plant karyology and karyosystematics. Int. Rev. Cytol., 196, 131-175.

Guerra, M. S. (1987a), Characterization of different types of condensed chromatin in Costus (Zingiberaceae). Plant Syst. Evol., 158, 107-115.
Guerra, M. S. (1987b), Cytogenetics of Rutaceae IV. Structure and systematic significance of interphase nuclei. Cytologia, 52, 213-222.

Heslop-Harrison, J. S.; Schwarzacher, K.; AnamthawatJonsson, A. R.; Leitch, M. and Leitch, I. J. (1991), In situ hybridization with automated chromosome denaturation. Technique, 3, 106-109.

Howell, W. M. and Black, D. A. (1980), Controlled silver staining of nucleolus organizer regions with a protective colloidal developer: a 1 step method. Experientia, 36, 1014-1015.

Ikeda, H. (1988), Karyomorphological studies on the genus Crepis with special reference to C-banding pattern. J. Sci., 22, 65-117.

Khoshoo, T. N. and Mahal, C. (1967), Versatile reproduction in Lantana camara. Curr. Sci., 20, 201203.

Kumar P. and Dutt B. (1989), Cytogenetic basis of breeding system in some verbenaceous species. Cytologia, 54, 347-353.

Moldenke, H. N. (1985), Notes on the genus Clerodendrum (Verbenaceae). Phytologia, 57, 303310.

Moscone, E. A.; Lambrou, M. and Ehrendorfer, F. (1996), Fluorescent chromosome banding in the cultivated species of Capsicum (Solanaceae). Plant Syst. Evol., 202, 37-63.

Natarajan, A. T. and Ahuja, M. R (1957), Cytotaxonomical studies in the genus Lantana. J. Ind. Bot. Soc., 36, 35-45.

Okada, H. (1995), Karyological studies of four genera of the Chloranthaceae. Plant Syst. Evol., 195, 177185.

O’ Leary, N.; Calvino, C. I.; Greizerstein, E.; Martinez, S. and Poggio, L. (2004), Further cytogenetical studies on diploid and polyploid species of Eryngium L. (Saniculoideae, Apiaceae) from Argentina. Hereditas, 140, 129-133.

Otto, S. P. and Whitton, J. (2000), Polyploid incidence and evolution. Ann. Rev. Genet., 34, 401-437.

Ozkan, H.; Levy, A. A. and Feldman, M. (2001), Allopolyploidy-induced rapid genome evolution in the wheat (Aegilops-Triticum) group. Plant Cell, 13, 1735-1747.

Raghavan, R. S. and Arora, C. M. (1960), Morphological and cytological studies in the genus Lantana L. Bull. Bot. Sur. India., 2, 299-303.

Ramam, V. S. and Kesavan, P. C. (1963), Chromosome numbers of a few horticultural plants. Sci. Cul., 29, 609-610.

Raven, P. H. (1975), The bases of angiosperm phylogeny: cytology. Ann. Mo. Bot. Gard., 62, 724764.

Redi, C. A.; Garagna, S.; Zacharias, H.; Zuccotti, M. and Capanna, E. (2001), The other chromatin. Chromosoma, 110, 136-147. 
Riley, R. and Chapman, V. (1958), Genic control of the cytological diploid behavior of hexaploid wheat. Nature, 182, 713-715.

Roser, M. (1994), Pathways of karyological differentiation in palms (Asteraceae). Plant Syst. Evol., 189, 83-122.

Salimena, F. R. G. (2000), Revisão taxonômica de Lippia L., sect. Rhodolippia Schauer (Verbenaceae). PhD Thesis, Universidade de São Paulo, São Paulo, Brasil.

Salimena, F. R. G. (2002), Duas novas espécies de Lippia sect. Rhodolippia (Verbenaceae) da América do Sul. Hickenia, 3, 145-147.

Sanders, R. W. (1987), Taxonomic significance of chromosome observations in Caribbean species of Lantana (Verbenaceae). Am. J. Bot., 74, 914-920.

Sanders, R. W. (2001), The genera of Verbenaceae in the southeastern United States. Harv. Pap. Bot., 5, 303-358.

Schmidt, R. (2002), Plant genome evolution: lessons from comparative genomics at the DNA level. Plant Mol. Biol., 48, 21-37.

Schwarzacher, T.; Ambros, P. and Schweizer, D. (1980), Application of Giemsa banding to orchid karyotype analyses. Plant Syst. Evol., 134, 293-97.

Shan, F.; Yan, G. and Plummer, J. A. (2003), Karyotype evolution in the genus Boronia (Rutaceae). Bot. J. Linn. Soc., 142, 309-320.
Singh, R. J. (1993), Plant cytogenetics. CRC Press, Boca Raton.

Stace, C. A. (1989), Plant taxonomy and biosystematics. Cambridge University Press, Cambridge.

Stace, C. A. (2000), Cytology and cytogenetics as a fundamental taxonomic resource for the $20^{\text {th }}$ and $21^{\text {st }}$ centuries. Taxon, 49, 451-477.

Sybenga, J. (1996), Chromosome pairing affinity and quadrivalent formation in polyploids: do segmental allopolyploids exist ? Genome, 39, 1176-1184.

Troncoso, N. S. (1980), Novedades taxonomicas em los Lantana y Lippia (Verbenaceas). Hickenia, 1, 227231.

Wendel, J. F. (2000), Genome evolution in polyploids. Plant Mol. Biol., 42, 225-249.

Widen, B. and Widen, M. (2000), Enzyme variation and inheritance in Glechoma hederaceae (Lamiaceae), a diploidized tetraploid. Hereditas, 132, 229-241.

Yang, S. X.; Gong, X.; Peng, H. and Wu, Z. Y. (2000), A cytogenetic study on the genus Pyrenaria complex (Theaceae). Caryologia, 53, 245-253.

Received: October06, 2006; Revised: May 10, 2007; Accepted: September 23, 2008. 